\title{
Determination of Total Flavonoid Content and Initial Test of Anticancer Activity of Faloak Leaves and Fruit Extracts (Sterculia urceolata Smith)
}

\author{
Apris A. Adu ${ }^{1}$, I. Gusti Ngurah Budiana ${ }^{2}$, Sarci M. Toy ${ }^{3}$, R. Pasi ikus Christa Wijaya ${ }^{3}$, Mas'amah $^{4}$, \\ Indra Yohanes Kiling ${ }^{5}$, Marylin S. Junias ${ }^{3}$ \\ ${ }^{1}$ Associate Professor and Dean, Faculty of Public Health, Nusa Cendana University, Indonesia, ${ }^{2}$ Associate \\ Professor, Faculty of Teacher Training and Education, Nusa Cendana University, Indonesia, ${ }^{3}$ Assistant \\ Professor, Faculty of Public Health, Nusa Cendana University, Indonesia, ${ }^{4}$ Assistant Professor, Faculty of \\ Social and Political Science, Nusa Cendana University, Indonesia, ${ }^{5}$ Assistant Professor, Faculty of Public \\ Health, Nusa Cendana University, Indonesia
}

\begin{abstract}
This study aimed to determine the total flavonoid content and anticancer activity of Faloak (Sterculia urceolata Smith) leaves and fruit extracts. Brine Shrimp Lethality Test (BSLT) method determined the anticancer activity. Testing the total flavonoid content of n-hexane extract of the Faloak leaves and fruit were 1558.5 and $498.5 \mathrm{ppm}$, respectively. The total flavonoid content of the ethyl acetate extract of Faloak leaves and fruit were 876.5 and $621.8 \mathrm{ppm}$, respectively. The ethanol extract of Faloak leaves and fruit's total flavonoid content was 338.5 and $1688.5 \mathrm{ppm}$. The anticancer activity test of the n-hexane extract of Faloak leaves and fruit showed that each extract's LC50 value was 31.417 and $50.736 \mathrm{ppm}$, respectively, and the $\mathrm{LC}_{50}$ value ethyl acetate extract of Faloak leaves and fruit were 119.68 and $77.59 \mathrm{ppm}$. The $\mathrm{LC}_{50}$ value of ethanol extract of Faloak leaves and fruit were 43.82 and $20.779 \mathrm{ppm}$, respectively. Both the leaves and fruit extract of Faloak had strong anticancer activity $(<1000 \mathrm{ppm})$. However, the extracts with the strongest anticancer activity were the ethanol extract of Faloak fruit and the n-hexane extract of Faloak leaves. Meanwhile, the extract with the highest amount of flavonoid content was the ethanol extract of Faloak fruit (1688.5 ppm), and the lowest amount was ethanol extract of the Faloak bark (4.5 ppm).
\end{abstract}

Keywords: faloak, treatment, information, flavonoids, and anticancer

\section{Introduction}

Indonesia is one of the developing countries that still have limitations in overcoming health problems and is prone to degenerative diseases ${ }^{1}$. Based on

\section{Corresponding author:}

Apris A. Adu

Associate Professor and Dean of Faculty of Public Health, Nusa Cendana University, Adi Sucipto Street, Kupang, East Nusa Tenggara, Indonesia 85001, E-mail: apris.adu@staf.undana.ac.id
Indonesia Basic Health Research data quoted from the Indonesian Ministry of Health's official website on World Cancer Day 2019, the incidence rate of cancer in Indonesia (136.2/100,000 population) ranks $8^{\text {th }}$ in Southeast Asia and $23^{\text {rd }}$ in Asia. The prevalence of tumors/cancer in Indonesia shows an increase from 1.4 per 1000 populations in 2013 to 1.79 per 1000 populations in 2018. Currently, cancer treatment can be done with chemotherapy, radiotherapy, and surgery. Some of the most commonly used chemotherapy drugs are antimetabolites, DNA interactive compounds, anti-tubulin compounds, hormones, and molecular 
targeting compounds ${ }^{2}$. In general, cancer drugs derived from synthetic chemical compounds do not work selectively. They might damage DNA in cancer cells and surrounding normal cells ${ }^{3}$.

The plants used in traditional alternatives treatments are known as herbal plants 4,5 . Natural antibiotic and drug ingredients can be derived from natural materials such as plants, animals, and terrestrial and marine microorganisms ${ }^{6}$. In Indonesia's tropical forests, there are about 30,000 plants, around 9,600 species have medicinal properties. Plants can produce chemical compounds regularly and in the balance as both primary and secondary metabolites. Most of the active compounds found in secondary metabolites are alkaloids, saponins, steroids, terpenoids, and flavonoids. The latter is widely used as antioxidants that can protect DNA/RNA against the bad effects of free radicals formed due to the oxidation of chemical carcinogens.

East Nusa Tenggara (NTT) has several indigenous plants with medicinal properties, one of which is the Faloak plant. The content of medicinal compounds in the Faloak plant is caused by this plant's ability to survive in dry climates and can even live between rocks. Plants will release medicinal compounds or bioactive compounds if they live in soil with minimal nutrients because these medicinal compounds are needed to sustain their life ${ }^{7,8}$. Besides using cancer cell cultures, testing for anticancer activity can also be done by carrying out the Brine Shrimp Lethality Test. Faloak plants can be developed as standard phytopharmaca products if a complete study has been carried out on the isolation of active compounds, activity tests, and clinical trials on Faloak plants.

\section{Methods}

This type of research is an experiment using a Completely Randomized Design (CRD) and analytical observation. This research was conducted in Kupang City in July-October 2020. The tests of anticancer activity and flavonoid content were carried out at the Bioscience and Chemistry Laboratory at the University of Nusa Cendana with the following stages.

\section{Extraction}

A total of $1 \mathrm{~kg}$ of dry powder of leaves and fruit of the Faloak plant were macerated, each with $5 \mathrm{~L}$ of $96 \%$ ethanol solvent for seven days. The extract which still contained solvent was then evaporated using a vacuum rotary evaporator to obtain a dry extract. Each dry extract was weighed to obtain the extracted content of each part of the Faloak plant. The extract was stored at $4^{\circ} \mathrm{C}$.

Test of Anticancer Activity using the Brine Shrimp Lethality Test (BSLT) Method on Faloak Plant Extracts

The first stage is the hatching of Artemia salina Leach eggs in seawater placed in the aquarium divided into two parts, namely the light and dark parts. After 24 hours, eggs laid in the dark part would hatch and move towards the light part. After the larvae were 48 hours old, they were ready to be used for testing. The second stage is the testing stage, where four series of extract concentrations were made, namely, 0, 10, 50, and $100 \mathrm{ppm}$. Fifty $\mu \mathrm{L}$ of dimethyl sulfoxide were added to the extract, followed by $5 \mathrm{~mL}$ of seawater, ten shrimp, a drop of $1 \%$ yeast solution, and diluted with seawater, and the volume reached $10 \mathrm{~mL}$. The concentration of 0 was a control because it did not contain extract. After 24 hours, the number of dead larvae was observed in each test tube. The LC50 value (the concentration that killed half of the bioindicator used) would be obtained from each extract through this test.

\section{Determination of Total Flavonoids}

Quercetin standard solution was weighed as much as $50 \mathrm{mg}$ then dissolved in $95 \%$ ethanol. Furthermore, a concentration series was made, for example, 10, 20, 40, 60, 80,100, 120, and $140 \mathrm{ppm}$. The standard solution series was added with $95 \%$ to $1 \mathrm{ml}$ ethanol, and $0.1 \mathrm{ml}$ of $10 \%$ aluminum chloride and $0.1 \mathrm{ml}$ of 
$1 \mathrm{M}$ potassium acetate were added. The final volume was adjusted with double-distilled water to $5.0 \mathrm{ml}$ in a measuring flask. Incubation for 25 minutes at room temperature and absorbance measured at wavelengths between 200-800 $\mathrm{nm}$. The absorbance measurement was compared to a blank. The standard curve equation was obtained from linear regression between quercetin (x) and absorbance (y) levels. The sample was dissolved in ethanol, then added with $\mathrm{AlCl} 3$ and incubated for 30 minutes at room temperature to measure the sample wavelength. After obtaining the sample's absorbance value, the total flavonoid content was calculated by the equation $\mathrm{y}=\mathrm{ax}+\mathrm{b}$.

Data collection from 83 respondents was carried out to obtain information on the number of Faloak tree uses based on the sub-district area, the part of the Faloak tree used, and sources of information regarding the properties of Faloak. The laboratory and test results are presented in the form of tables and narration.

\section{Results and Discussion}

Sterculia quadrifida R.Br. is occasionally used as medicine by natives of East Nusa Tenggara, scattered on the island of Timor, starting from Kupang city to Malaka regency. People know the Faloak tree by various local names, such as Faloak, Flolo, and Nitaen ${ }^{8}$. This plant is believed to have properties to treat liver disorders so that it is still sought and used as traditional medicine by the community. In terms of socio-cultural characteristics, the belief in traditional medicines' efficacy and use is still strong from generation to generation. The natives believe that traditional medicines are considered safer, and side effects are low or even non-existent. The cheaper cost factor is a consideration for people to use traditional medicine instead of paying for doctor services and buying pharmacies.

Several parts are utilized from the Faloak plant: roots, stems, bark, leaves, and fruit. We surveyed 83 natives who are frequent users of Faloak as traditional medicine. People mostly use Faloak bark (61\%) for traditional medicine compared to other parts of the tree. The often done treatment is boiling the bark with a certain amount of water to drink, presumably due to a previous consumer's recommendation who experienced recovery from consuming Faloak bark boiled water. This finding is in line with Siswadi et al. (2016) research, which shows that most respondents chose the Faloak tree's bark as raw material for herbal medicine. Most Faloak consumers are in the Alak sub-district to treat liver disorders (54\%). The least consumers are in the Kelapa Lima sub-district, following the area's characteristics. In the Alak subdistrict, there are still many forests and trees, making it possible to find Faloak trees.

However, information regarding the Faloak tree's properties as traditional medicine is obtained from various sources. The sources of information most accessed by the community to find out the benefits of Faloak are the internet (30\%), friends and neighbors, and family experiences (43\%). The experiences of close people such as friends, neighbors, and family are the basis of recommendation. The community believes in it and uses Faloak as traditional medicine for generations. The lack of access to empirical research prevents Faloak herbal medicine's proper use, so intensive efforts must be made to provide information in this regard.

Table 1. Extract Content in Faloak Plants

\begin{tabular}{|c|c|c|c|}
\hline No. & Extract Names & Extract Colors & Extract Content (\% w/w) \\
\hline 1. & n-hexane extract of Faloak leaves & Green & 15.50 \\
\hline 2. & Ethyl acetate extract of Faloak leaves & Light yellow & 21.50 \\
\hline 3. & Ethanol extract of Faloak leaves & Pink & 53.0 \\
\hline 4. & n-hexane extract of Faloak fruit & Green & 20.65 \\
\hline 5. & Ethyl acetate extract of Faloak fruit & Light yellow & 25.25 \\
\hline 6. & Ethanol extract of Faloak fruit & Pink & 54.10 \\
\hline
\end{tabular}


Table 2. Results of Anticancer Activity Testing with the BSLT Method

\begin{tabular}{|c|c|c|c|c|c|}
\hline \multirow{2}{*}{ No. } & \multirow{2}{*}{ Extract names } & \multirow{2}{*}{$\begin{array}{c}\text { Extract concentration } \\
(\text { (ppm) }\end{array}$} & \multicolumn{2}{|c|}{$\begin{array}{c}\text { Shrimp larvae mortality } \\
\text { rate (number) }\end{array}$} & \multirow{2}{*}{$\mathrm{LC}_{50}$ Value } \\
\hline & & & Sample & Control & \\
\hline \multirow{3}{*}{1.} & \multirow{3}{*}{ n-hexane of Faloak leaves } & 10 & 5 & 0 & \multirow{3}{*}{31.417} \\
\hline & & 50 & 8 & 0 & \\
\hline & & 100 & 10 & 0 & \\
\hline \multirow{3}{*}{2.} & \multirow{3}{*}{ n-hexane of Faloak fruit } & 10 & 3 & 0 & \multirow{3}{*}{50.736} \\
\hline & & 50 & 6 & 0 & \\
\hline & & 100 & 8 & 0 & \\
\hline \multirow{3}{*}{3.} & \multirow{3}{*}{ Ethyl acetate of Faloak leaves } & 10 & 1 & 0 & \multirow{3}{*}{119.68} \\
\hline & & 100 & 3 & 0 & \\
\hline & & 1000 & 4 & 0 & \\
\hline \multirow{3}{*}{4.} & \multirow{3}{*}{ Ethyl acetate of Faloak fruit } & 10 & 3 & 0 & \multirow{3}{*}{77.59} \\
\hline & & 50 & 4 & 0 & \\
\hline & & 100 & 6 & 0 & \\
\hline \multirow{3}{*}{5.} & \multirow{3}{*}{ Ethanol of Faloak leaves } & 10 & 4 & 0 & \multirow{3}{*}{43.82} \\
\hline & & 50 & 7 & 0 & \\
\hline & & 100 & 8 & 0 & \\
\hline \multirow{3}{*}{6.} & \multirow{3}{*}{ Ethanol of Faloak fruit } & 10 & 7 & 0 & \multirow{3}{*}{20.779} \\
\hline & & 50 & 9 & 0 & \\
\hline & & 100 & 10 & 0 & \\
\hline
\end{tabular}

\section{Extraction Results}

Extraction is carried out by the maceration method using the like-dissolve-like principle, meaning that compounds that have similar polarity properties will be attracted by solvents or solvents that have the same polarity. In this study, the medicinal compounds contained in the Faloak plant were extracted or withdrawn using three solvents with different polarities, namely, n-hexane (nonpolar), ethyl acetate (semipolar), and ethanol (polar). The use of these three different types of solvents is intended so that all medicinal compounds can be withdrawn. Faloak plant samples, both leaves, and fruit were used as a dry powder. The powder form sample aims to expand the contact area so that the bioactive compounds can be attracted as much as possible. 
The extraction process results showed that the extract's color using n-hexane solvent was all green, both on the leaves and fruit, indicated that the green chlorophyll is extracted. Meanwhile, the yellow color of the extract using ethyl acetate as a solvent was caused by the extraction of carotene compounds. All ethanol extracts are red; this is due to the polar compounds' character, which usually gives a red color (Table 1). The ethanol extract content is higher than the ethyl acetate extract and n-hexane extract due to the medicinal compounds' nature.

\section{Anticancer Activity}

Artemia salina L. larvae are simple organisms from marine life that are very small and have a high sensitivity to toxicity. Artemia salina L. has tolerance (adaptability) to a very wide salt range, a faster life cycle, and is easy to breed. Larvae used are aged 48 hours (called a nauplius). At that age, the larvae of Artemia salina L. are still very sensitive. The membrane covering the nauplius' body is still thin. The bioactive compounds in the Faloak extract can diffuse into the larvae, so the death of Artemia salina L. is caused by these compounds' presence. Also, at that age, the larvae experience significant growth. The nauplius phase is when cells divide in a very active mitosis manner and is identical to mitotic and abnormal division in cancer cells. Data on the results of testing for anticancer activity using the BSLT method are presented in Table 2.

The BSL test results show that the n-hexane extract has an $\mathrm{LC}_{50}$ value range from 31 to $50 \mathrm{ppm}$. While the ethyl acetate extract has a range of 77 to $119 \mathrm{ppm}$, and the ethanol extract has an $\mathrm{LC}_{50}$ value ranging from 20 to $43 \mathrm{ppm}$. The smallest $\mathrm{LC}_{50}$ value is found on the ethanol extract of Faloak fruit. The ethanol extract of Faloak fruit can kill the strongest cytotoxic cells. Meanwhile, the highest $\mathrm{LC}_{50}$ value is found on the ethyl acetate extract of Faloak leaves, which is almost $120 \mathrm{ppm}$. The highest $\mathrm{LC}_{50}$ value of ethyl acetate extract is since bioactive compounds rarely have medium polarity properties. In general, all extracts have the potential as anticancer because chemical compounds have bioactive potential if the $\mathrm{LC}_{50}$ value is less than $1,000 \mu \mathrm{g} / \mathrm{ml}$.

Based on the BSL test results, it can be said that Faloak fruit has good potential because it has the smallest $\mathrm{LC}_{50}$ value, meaning that it has the best biological activity. So far, the people of East Nusa Tenggara only know about using the Faloak bark as medicine. Compared with previous studies, the ethanol extract of Faloak fruit had a better $\mathrm{LC}_{50}$ value than the ethanol extract of God's crown (Phaleria macrocarpa (Scheff.) Boerl.) fruit, which had an $\mathrm{LC}_{50}$ value of $30.42 \mathrm{ppm}$. The ethanol extract of Faloak fruit has much better activity than the Madeira-vine (Anredera cordifiola (Ten) Steenis) leaves.

\section{Flavonoid Content}

Flavonoid compounds that function as anticancer are quercetin and kaempferol. The ability of flavonoids as anticancer substances is due to their ability to prevent cell damage caused by free radicals. Flavonoids are included in polyphenol compounds, secondary metabolites from plants, and have acted as anticancer. Flavonoids contain quercetin, which comes from the sub-class of flavonols. Quercetin, genistein, or flavopiridol can be used as an ingredient in cancer drugs ${ }^{9}$.

The results of determining the total flavonoid content of the Faloak plant extract show that the n-hexane extract of Faloak leaves and the ethanol extract of Faloak fruit have the highest total flavonoid content, namely $1558.5 \mathrm{ppm}$ and $1688.5 \mathrm{ppm}$. If the total flavonoid value is converted to percent $\mathrm{w} / \mathrm{w}$, then the total flavonoid content in the n-hexane extract of Faloak leaves and the ethanol extract of Faloak fruit are $7.79 \%$ and $8.44 \%$, respectively. Every $20 \mathrm{~g}$ of Faloak leaves contains a total of 1.559 grams of flavonoids, and every $20 \mathrm{~g}$ of Faloak fruit contains 1.689 grams of flavonoids. The lowest content of flavonoids is found in the ethanol extract of bark, which is $4.5 \mathrm{ppm}$.

Total flavonoid content in the n-hexane extract of 
Faloak leaves and the ethanol extract of Faloak fruit was higher than in the n-hexane extract Syzygium polycephalum Miq fruit ${ }^{10}$ and the ethanol extract of Indian Jujube leaves ${ }^{11}$ either. The results of determining total flavonoid content were related to the bioactivity test results. The leaf n-hexane extract's bioactivity had the smallest $\mathrm{LC}_{50}$ value (the best bioactivity) than the three $n$-hexane extracts. The anticancer activity was related to the flavonoid content of a sample. Two examples of flavonoid compounds that function as anticancer compounds are artelastoxanthone (a) and artonol A (b), showing their cytotoxicity effects on some of the cancer cells tested. Artelastoxanthone compounds appear to be more effective in suppressing the growth of Hep 3B, MCF-7, and HT-29 cells except for A549; whereas artonol A was more effective on A549, MCF-7, and HT-29 cells except for Hep 3B7.

\section{Conclusion}

Based on the research results, it was found that the most used part of the Faloak tree traditionally is its bark. The anticancer activity test showed that all extracts, both leaves, and fruit of Faloak, had strong anticancer activity $(<1000 \mathrm{ppm})$. However, the extracts with the strongest anticancer activity were the ethanol extract of Faloak fruit and the n-hexane extract of Faloak leaves. While the extract that had the highest amount of flavonoid content was the ethanol extract of Faloak fruit (1688.5 ppm), and the lowest was the ethanol extract of the Faloak tree bark (4.5 ppm).

Conflict of Interest: There are no conflicts of interest.

Source of Funding: The study was a self-funded project.

Ethical Clearance: This study was carried out after obtaining ethical approval from the Institutional Ethics Committee on the Nusa Cendana University in June 2020.

\section{References}

1. Handajani A, Roosihermiatie B, Maryani $\mathrm{H}$. Faktor-Faktor Yang Berhubungan Dengan Pola Kematian Pada Penyakit Degeneratif Di Indonesia. Bul Penelit Sist Kesehat. 2012;13(1). doi:10.22435/bpsk.v13i1Jan.2755

2. Zafrial RM, Amalia R. Artikel Tinjauan: Anti Kanker dari Tanaman Herbal. J Ilm Farm Indones. 2018;16(1):15-23. http://jurnal.unpad. ac.id/farmaka/article/viewFile/17332/pdf

3. Cheung-Ong K, Giaever G, Nislow C. DNAdamaging agents in cancer chemotherapy: Serendipity and chemical biology. Chem Biol. 2013;20(5):648-659. doi:10.1016/j. chembiol.2013.04.007

4. Hakim AR, Saputri R. Identifikasi Senyawa Kimia Ekstrak Etanol Mentimun (Cucumis sativus L.) dan Ekstrak Etanol Nanas (Ananas comosus (L) Merr.). J Pharmascience. 2017;4(1):34-38. doi:10.20527/jps.v4i1.5753

5. Kardinan A, Kusuma FR. Hidup Sehat Secara Alami. In: Meniran Penambah Daya Tahan Tubuh Alami. Agro Media Pustaka; 2004.

6. Shinde P, Banerjee P, Mandhare A. Marine natural products as source of new drugs: a patent review (2015-2018). Expert Opin Ther Pat. 2019;29(4):283-309. doi:10.1080/13543776.201 9.1598972

7. Budiana IGN. Uji Hepatoprotektif Ekstrak Etanol Kulit Batang Faloak (Sterculia Urceolata Smith).; 2000.

8. Siswadi, Raharjo AS, Pujiono E, Saragih GS, Rianawati H. Pemanfaatan Kulit batang Faloak (Sterculia quadrifida R.Br.) Sebagai Bahan Baku Obat Herbal di Pulau Timor. In: SEMINAR NASIONAL BIODIVERSITAS SAVANA NUSA TENGGARA. Balai Penelitian dan Pengembangan Lingkungan Hidup dan Kehutanan Kupang; 2016. doi:10.5281/zenodo.3353763

9. Ravishankar D, Rajora AK, Greco F, Osborn HMI. Flavonoids as prospective compounds for anticancer therapy. Int $J$ Biochem Cell Biol. 2013;45(12):2821-2831. doi:10.1016/j. biocel.2013.10.004 
576 Medico-legal Update, July-September 2021, Vol.21, No. 3

10. Rahmiyani I. Penetapan Kadar Flavonoid Total Ekstrak Buah Kupa (Shyzigium Polycepalum Miq.) Menggunakan Spektrofotometri UvVis. J Kesehat Bakti Tunas Husada J Ilmuilmu Keperawatan, Anal Kesehat dan Farm. 2018;17(2):487. doi:10.36465/jkbth.v17i2.276
11. Haeria, Hermawati, Pine ATUD. Penentuan Kadar Flavonoid Total dan Aktivitas Antioksidan Ekstrak Etanol Daun Bidara (Ziziphus spina-christi L.) Haeria,. J Pharm Med Sci. 2016;1(2):57-61. 